\title{
Factor Associated with Development Disorder in Children
}

\section{Gusti Ayu Trisna Windiani", Vanessa Lini Gunawan, I Gusti Agung Ngurah Sugitha Adnyana, Soetjiningsih}

Department of Child Health, Faculty of Medicine, Udayana University, Denpasar, Indonesia

\section{Email address:}

trisnawindianidr@yahoo.co.id (I G. A. T. Windiani), vanessalinigunawan@gmail.com (V. L. Gunawan), sugad168@yahoo.com (I G. A. N. S. Adnyana), prof_soetji@yahoo.com (Soetjiningsih)

${ }^{*}$ Corresponding author

\section{To cite this article:}

I Gusti Ayu Trisna Windiani, Vanessa Lini Gunawan, I Gusti Agung Ngurah Sugitha Adnyana, Soetjiningsih. Factor Associated with Development Disorder in Children. American Journal of Pediatrics. Vol. 6, No. 3, 2020, pp. 234-239. doi: 10.11648/j.ajp.20200603.20

Received: May 6, 2020; Accepted: May 25, 2020; Published: June 15, 2020

\begin{abstract}
Early detection of growth and development delay is important so that interventions can be carried out on time. Knowing the factors associated with developmental disorders in children is important in efforts to improve the quality of life of children and reduce the prevalence of these disorders in general. This study aims to determine the factor associated with developmental disorder in the Sanglah General Hospital Growth and Development clinic in 2018. This research is a retrospective cross sectional study. The research data was obtained from the outpatient register at the Growth and developmental clinic, Sanglah General Hospital. The subjects of this study were all patients who visited in RSUP Sanglah Denpasar from January 1st, 2018 to December 31st, 2018. There were 363 patient with developmental disorder in a year, most cases (37.5\%) were global developmental delays. The majority of patients with developmental disorder were aged 2-5 years (47.9\%), were male (66.7\%), had normal birth weight $(69.9 \%)$ and had vaginal birth $60.4 \%$. The majority of patients were found with comorbidities (50.4\%), and epilepsy $(12.6 \%)$ were the most common comorbidities found among patients. Child's gender (PR 2.687; 96\%CI 1.829-3.945; $\mathrm{p}=0.001$ ), parents level of education (PR 2.223; 95\%CI 1.414-3.497; $\mathrm{p}=0.001$ ), birth weight (PR 2.066; 95\%CI: 1.290-3.310; $\mathrm{p}=0.001$ ), and nutritional status (PR 2.014; 95\%CI 1.312-23.091; $\mathrm{p}=0.001$ ) was associated with developmental dissorder. This research proved that child's gender, parents level of education, birth weight, and nutritional status had a significant role in children's development disorders.
\end{abstract}

Keywords: Children, Developmental Disorder, Factor Associated, Growth and Development Clinic

\section{Introduction}

The early period of a child's life is an important phase of growth and development. Cognitive, social, and emotional development of the brain continues to develop throughout life. The growth and development of the brain has a heterogeneous timeline. The structure and capacity of the brain is formed early in life until before the age of two. Many policies stress the importance of the "first 1000 days" as a golden period of future child development. The loss of this golden period will cause failure of optimizing brain development early in life which will have long-term consequences $[1,2]$.

Developmental delays occur when a child shows failure in achieving milestones according to age [3]. Early detection of growth and development deviations is very important. Through early detection, appropriate prevention, and interventions can be given in the golden period of growth and development. With early detection, interventions can be carried out on time so that development can be maximized and functional limitations can be minimized [4].

The American Academy of Pediatrics (AAP) recommends screening child development with validated screening devices at 9, 18, and 24 months or 30 months and screening for autism spectrum disorders at 18 and 24 months. In children with risk factors such as premature birth, low birth weight, screening must be done earlier. Interventions carried out in the first 2 years of life have an impact on better long-term outcomes including education and productivity of a child in the future [5, $6]$.

Early detection of child developmental deviations in developed countries has been carried out consistently in daily practice and has proven effective in identifying abnormalities 
that are often overlooked [6]. Early detection of child developmental delay is still not optimal in developing countries. World Health Organization (WHO) estimates that as many as 250 million or $43 \%$ of children do not reach optimal development potential [8].

The Indonesian Pediatric Association states that around 5\% to $10 \%$ of children are estimated to experience developmental delays. Developmental disorders of toddlers that are often found include speech/ language disorders, cerebral palsy, Down syndrome, short stature, autism spectrum disorders, mental retardation and attention-deficit/hyperactivity disorder (ADHD) [9].

Previous research mentions several factors related to developmental disorders in children. These factors include the age of the child (39.9\%), maternal education (36.2\%), comorbidities $(26.2 \%)$ and nutritional status $(69.7 \%)$ [9, 10]. Nutritional deficiencies will affect development central and peripheral nervous system and neurological abnormalities. ${ }^{11}$ Parents with low education are associated with a lack of parental ability to stimulate [9-11].

Knowing the factors associated with developmental disorders in children is important in efforts to improve the quality of life of children and reduce the prevalence of these disorders in general. Based on this background, this becomes important to be further investigated at Sanglah General Hospital as the main referral hospital in Bali, West Nusa Tenggara, East Nusa Tenggara, East Timor.

\section{Materials and Methods}

This research is a retrospective study with a cross-sectional approach which records the factors associated with development disorder in the Growth and developmental clinic, Sanglah General Hospital. The basic data of the research subjects were obtained from the outpatient register at the Sanglah General Hospital medical record.

The subjects of this study are all childrens who visited at the Growth and developmental clinic, Sanglah General Hospital from 1 January 2018 to 31 December 2018 who meet the inclusion and exclusion criteria. Samples will be excluded if the data is incomplete.

Based on the sample size formula of unpaired categorical samples, using the proportion of each risk factor for developmental disorders based on literature namely the age of the child (39.9\%), maternal education $(36.2 \%)$, comorbidities (26.2\%) and nutritional status $(69.7 \%)$ as the $\mathrm{P}$ value and the precision value (d) of $10 \%$, the minimum sample size obtained in this study was 223 samples which were then further analyzed statistically.

Developmental disorder is one of several disorders that interrupt normal development in childhood. They may affect a single area of development (specific developmental disorders) or several (pervasive developmental disorders). Cases of developmental disorders are enforced through anamnesis, physical examination and systematic development screening. Autism spectrum disorders, global delay developmental, attention-deficit/hyperactivity disorder (ADHD), oppositional defiant disorder are diagnosed according to DSM-5 (Diagnostic and Statistical Manual of mental Disorder) criteria. Gross motor delay are diagnosed if there is a late motor development that is incompatible with age-appropriate development. Speech and language delays are delays in the language sector experienced by a child who is diagnosed using the Capute scale. Intellectual disability is diagnosed if an IQ test $<70$. The diagnosis of clinically Down syndrome is based on the results of history taking and physical examination. Cerebral palsy is established based on the Levine criteria. Hearing loss is established through examination of Brainstem Evoked Response Audiometry (BERA).

All data is collected and then processed using a computer using the SPSS Statistics 22.0 program. Categorical variables are described in numbers (n) and percentages (\%). Data is presented in the form of narratives and tables. The relationship between developmental disorders and nutritional status was analyzed using X2 and considered statistically significant if the $\mathrm{p}$ value $<0.05$.

\section{Results}

During the period of 2018, there were 558 patients recorded in the register of patients at the Sanglah General Hospital medical record. Of the 558 patients, 38 patients had incomplete data registers and were excluded. Of 520 patients, 363 patient having developmental disorders.

The characteristics of the study subjects were divided into age, sex, nutritional status, birth weight, mode of delivery, parental education, and presence of comorbidities Of the 363 patients with developmental disorder, most were 2-5 years old $(47.9 \%)$ and the majority were male $(66.7 \%)$. Based on birth weight and delivery method, 254 patients $(69.9 \%)$ had normal birth weight and $219(60.4 \%)$ had vaginal births. The majority of patients have fathers (38.8\%) and mothers (37.5\%) with the highest level of education of high school. The majority of patients' nutritional status was obtained with good nutrition $(50.4 \%)$. Most of patients were found with comorbidities $(50.4 \%)$ and epilepsy $(12.6 \%)$ were the most common comorbidities in patients. Characteristics of children with developmental disorders are shown in Table 1.

Table 1. Characteristicsof children with developmental disorder.

\begin{tabular}{ll}
\hline Variable & $\mathbf{N}=\mathbf{3 6 3}$ \\
\hline Age, $\mathrm{n}(\%)$ & \\
0 month-12 months & $45(12.4)$ \\
1 -2 years & $77(21.2)$ \\
2 - 5 years & $174(47.9)$ \\
5 - 12 years & $64(17.6)$ \\
$12-18$ years & $3(0.8)$ \\
Sex, $\mathrm{n}(\%)$ & \\
Male & $242(66.7)$ \\
Female & $121(33.3)$ \\
Birth weight (gram), n (\%) & \\
$>2500$ & $254(69.9)$ \\
$1500-<2500$ & $88(24.2)$ \\
$1000-<1500$ & $17(4.7)$ \\
$<1000$ & $4(1.1)$ \\
Mode of delivery, $\mathrm{n}(\%)$ & \\
\hline
\end{tabular}




\begin{tabular}{ll}
\hline Variable & $\mathbf{N}=\mathbf{3 6 3}$ \\
\hline Spontaneous Vaginal & $219(60.4)$ \\
Forceps & $14(3.9)$ \\
Vacuum & $3(0.8)$ \\
Caesarian section & $127(35)$ \\
Father's level of education, $\mathrm{n}(\%)$ & \\
Elementary school & $52(14.3)$ \\
Junior high school & $73(20.1)$ \\
Senior high school & $141(38.8)$ \\
Diploma & $42(11.6)$ \\
Bachelor's & $55(15.2)$ \\
Mother's level of education, n (\%) & \\
Elementary school & $61(16.8)$ \\
Junior high school & $83(22.9)$ \\
Senior high school & $136(37.5)$ \\
Diploma & $31(8.5)$ \\
Bachelor's & $52(14.3)$ \\
Nutritional status & \\
Moderate malnutrition & $155(29.8)$ \\
Well nourished & $294(56.5)$ \\
Overweight & $32(6.2)$ \\
Obese & $22(4.2)$ \\
Severe malnutrition & $17(3.3)$ \\
Comorbidity n (\%) & \\
With comorbidity & $183(50.4)$ \\
Epilepsy & $46(12.6)$ \\
Congenital hypothyroidism & $30(8.2)$ \\
Microcephaly & $28(7.7)$ \\
Congenital heart disease & $23(6.3)$ \\
History of brain infection & $21(5.9)$ \\
Hydrocephalus & $16(4.4)$ \\
Clinically congenital rubella & $15(4.1)$ \\
syndrome & \\
History of brain hemorrhage & $6(1.7)$ \\
Infantile spasm & $5(1.4)$ \\
Congenital Talipes Equinovarus & $3(0.8)$ \\
Pierre Robin syndrome & $2(0.5)$ \\
Human Immunodeficiency Virus & $2(0.5)$ \\
History of ventricular cysts & $1(0.3)$ \\
\hline
\end{tabular}

\begin{tabular}{ll}
\hline Variable & $\mathbf{N}=\mathbf{3 6 3}$ \\
\hline Noonan syndrome & $1(0.3)$ \\
Without comorbidity & $180(49.6)$ \\
\hline
\end{tabular}

Most cases of developmental disorders were delays in global delay development (37.5\%), delayed speech (21\%), attention-deficit/hyperactivity disorder (ADHD) (9.4\%), cerebral palsy $(7.4 \%)$, intellectual disability (6.6\%), clinically Down syndrome $(6.1 \%)$. Table 2 shows various cases of developmental disorders in the Growth and developmental clinic, Sanglah General Hospital.

Table 2. Type of Developmental Disorder Cases.

\begin{tabular}{ll}
\hline Type of cases, $\mathbf{n}(\mathbf{\%})$ & $\mathbf{N}=\mathbf{3 6 3}$ \\
\hline Global delay development & $136(37.5)$ \\
Delayed speech & $82(22.6)$ \\
Attention-deficit/hyperactivity disorder & $34(9.4)$ \\
Cerebral Palsy & $27(7.4)$ \\
Intellectual disability & $24(6.6)$ \\
Clinically Down syndrome & $22(6.1)$ \\
Gross motor delay & $19(5.2)$ \\
Autism spectrum disorders & $13(3.6)$ \\
Hearing disorders & $5(1.3)$ \\
Oppositional defiant disorder & $1(0.3)$ \\
\hline
\end{tabular}

There was significant relationship between developmental disorders and male gender (PR 2.687; 96\%CI 1.829-3.945; $\mathrm{p}=0.001$ ), parents level of education (PR 2.223; 95\%CI 1.414-3.497; $\mathrm{p}=0.001$ ), birth weight (PR 2.066; 95\%CI: $1.290-3.310 ; \mathrm{p}=0.001$ ), and nutritional status (PR 2.014; 95\%CI 1.312-23.091; $\mathrm{p}=0.001$ ) (Table 3).

Table 3. Factor associated with developmental disorder.

\begin{tabular}{|c|c|c|c|c|c|}
\hline \multirow{2}{*}{ Variable } & \multicolumn{2}{|c|}{ Developmental Disorder } & \multirow[b]{2}{*}{ PR } & \multirow{2}{*}{ P Value } & \multirow{2}{*}{$95 \%$ CI } \\
\hline & Yes & No & & & \\
\hline \multicolumn{6}{|l|}{ Gender, n (\%) } \\
\hline Male & $242(78.3)$ & $67(21.7)$ & \multirow{2}{*}{2.687} & \multirow{2}{*}{0.001} & \multirow{2}{*}{$1.829-3.945$} \\
\hline Female & $121(57.3)$ & $90(42.7)$ & & & \\
\hline \multicolumn{6}{|c|}{ Father's level of education, $n(\%)$} \\
\hline Low educated & $125(80.6)$ & $30(19.4)$ & \multirow{2}{*}{2.223} & \multirow{2}{*}{0.001} & \multirow{2}{*}{$1.414-3.497$} \\
\hline Highly educated & $238(80.6)$ & $127(34.8)$ & & & \\
\hline \multicolumn{6}{|c|}{ Mother's level of education, $n(\%)$} \\
\hline Low educated & $144(77.0)$ & $43(23.0)$ & \multirow{3}{*}{1.743} & \multirow{3}{*}{0.007} & \multirow{3}{*}{$1.158-2.624$} \\
\hline Highly educated & $219(65.8)$ & $114(34.2)$ & & & \\
\hline Mode of delivery, & & & & & \\
\hline Spontaneus & $219(70.9)$ & $90(29.1)$ & 1.217 & 0.324 & $0.827-1.790$ \\
\hline$<2500$ & $109(80.1)$ & $27(19.9)$ & \multirow{3}{*}{2.066} & \multirow{3}{*}{0.002} & \multirow{2}{*}{$1.290-3.310$} \\
\hline$\geq 2500$ & $254(66.1)$ & $130(33.9)$ & & & \\
\hline \multicolumn{4}{|c|}{ Nutritional status, n (\%) } & & \\
\hline Malnutrition & $136(79.1)$ & $227(65.2)$ & \multirow{2}{*}{2.014} & \multirow{2}{*}{0.001} & \multirow{2}{*}{$1.312-3.091$} \\
\hline Not malnutrition & $227(65.2)$ & $121(34.8)$ & & & \\
\hline
\end{tabular}

\section{Discussion}

This study investigated the factors associated with developmental disorders in the Growth and developmental clinic, Sanglah General Hospital. There were 363 patients with developmental disorders who meet the criteria.

Variables significantly associated with developmental disorder included male gender, parents level of education, birth weight, and nutritional status. In this study, 78,3\% male 
participant have developmental disorders (PR 2.687; 96\%CI $1.829-3.945 ; \mathrm{p}=0.001)$. These results are similar to the study of Shevel et al, which found that the majority of patients with developmental delay referred to the Montreal Children's Hospital growth and development clinic were male (74.1\%) [12]. Study in Iran by Akbari found that the incidence of developmental delay was 1.5-4.7 times higher in men than in women [13]. The role of genetics in gender influences the cognitive, linguistic, and social domains. Suwarba et al, added that the majority of patients with global delays at Cipto Mangunkusumo Hospital in Jakarta were male (63\%) [14]. The underlying cause of this is still unclear. Some mechanisms are thought to underlie the higher incidence of developmental delay in men. Several studies have shown that men are more susceptible to perinatal exposure (such as infection, malnutrition, stress) and more susceptible to genetic mutations. This is because men carry the $\mathrm{Y}$ chromosome and Y-linked traits genes whereas both men and women can carry the $\mathrm{X}$ chromosome gene [15]. Several X or Y chromosome genes have been identified to cause developmental disorders such as fragile $\mathrm{x}$ syndrome, Coffin-lowry syndrome, creatin transporter defects, and oculocerebrorenal syndromes or behavioral disorders such as ADHD, autism spectrum disorders [14]. Another possible mechanism is increased testosterone exposure during critical periods of fetal development. Increased exposure to testosterone can cause permanent changes in behavior. Women have high exposure to estrogen and oxytocin during fetal development. Oxytocin plays a role in social behavior and along with estrogen working in the amygdala can reduce the level of social anxiety [15].

In this study, it was found that the majority of patients with developmental disorders were treated at the Growth and developmental clinic, Sanglah General Hospital at the age of $2-5$ years $(47.9 \%)$. A similar finding was presented by Shevel et al, in her study which aimed to determine the profile and referral patterns of children with suspected developmental delay to the subspecialty clinic at Montreal Children's Hospital [12]. The average age of children brought to the subspecialty clinic was 22.9 months. In this study it was found that parents were worried earlier about motor delays. This reflects parental awareness and parental sensitivity to the attainment of a child's motor milestone [12]. Suwarba et al, found that the average age of the first time a child was diagnosed with global developmental delays at Cipto Mangunkusumo Hospital was 21.8 months. Delays in specialist evaluation can be caused by the possibility of parents not communicating to health workers or the existence of a "wait and see" culture before bringing children to specialist services [14].

Based on birth weight, children who had low birth weigh were more likely experienced developmental disorder (PR 2.066; 95\%CI: 1.290-3.310; $\mathrm{p}=0,001)$. These results are in accordance with the study of Charan and Vagha which found that $57.8 \%$ of developmental delay patients in Acharya Vinoba Bhave Rural India Hospital have birth weight $>2.5 \mathrm{~kg}$ [16] The risk of developmental disorders is higher in low birth weight infants $(\mathrm{p}=0.0001)$.

Based on the type of delivery, mode of delivery have no correlation with developmental disorder. Vameghi et al, reported that there was no relationship between the mode of delivery and developmental disorders [19].

This study found that malnutrition has a statistically significant relationship with developmental disorders as indicated by the value of PR 2.014; 95\%CI 1.312-23.091; $\mathrm{p}=0.001$. Suwarba et al, found that $45 \%$ of cases of global development delays in RSUPN Dr. Cipto Mangunkusumo was accompanied with undernutrition and malnutrition [14]. This may be due to eating difficulties that occur in patients due to oromotor disorders. Children with $\mathrm{BB} / \mathrm{U}$ below 2 standard deviations have 10 times the risk of developmental delays compared to children with good nutrition [20]. Nutritional status is an important indicator of the overall health status and wellbeing of children. The impact of poor nutritional status may eventually lead to poor growth and nutritional deficiency. Nutritional deficiencies will affect the development of the central and peripheral nervous system and cause neurological abnormalities [14].

A high level of parental education is a positive factor for children's development. Parents with high levels of education will interact with children in more varied and complex languages. The parents will also be more supportive of children to read, stimulating children to achieve optimal cognitive development [21]. In this study it was found that the parents with low levels of education have risk for having child with developmental disorder (father: PR 2.223; 95\%CI 1.414-3.497; $\mathrm{p}=0.001$, mother: PR 1,743; 95\%CI 1.158-2.624; $\mathrm{p}=0.07$ ). Parents with a high level of education have sufficient knowledge of child development, making this a supporting factor for early detection and parental response to bring the child to treatment. Low level of parental education is a risk for delays in child development. This is due to the lack of parental ability to stimulate [22].

The majority of patients were found with comorbidities (50.4\%). The comorbidities obtained were epilepsy (12.6\%), congenital hypothyroidism (8.2\%), microcephaly $(7.7 \%)$, congenital heart disease $(6.3 \%)$, history of brain infection (5.9\%), hydrocephalus $(4.4 \%)$, clinical congenital rubella syndrome $(4.1 \%)$, history of brain hemorrhage $(1.7 \%)$, infantile spasm (1.4\%), Congenital Talipes Equinovarus (CTEV) (0.8\%), Pierre Robin syndrome (0.5\%), Human Immunodeficiency Virus (HIV) $(0.5 \%)$ history of ventricular cysts $(0.3 \%)$, noonan syndrome $(0.3 \%)$. Chen et al, found that $62.8 \%$ of children with developmental delay were related to biological factors $(20 \%$ with genetic defects or congenital abnormalities and $16.3 \%$ with central nervous system lesions) and $14.2 \%$ of children with developmental delays were related to environmental factors such as the role of parents, psychological disorders in children, or violence in children [23]. Oeseburg et al, reported that the prevalence of epilepsy in children with intellectual disabilities and global developmental delays ranged from $5.5 \%$ to $35 \%$ [24]. Similar findings were presented by Suwarba et al, in his study that the etiology of global development delays in RSUPN Dr. Cipto 
Mangukusomo Jakarta is cerebral dysgenesis (21.9\%), cerebral palsy (11.9\%), TORCH infections $(9.9 \%)$, genetic syndromes $(7.3 \%)$, congenital metabolic abnormalities such as congenital hypothyroidism (4.6\%) and no known cause (35.8\%) [14].

The most types of outpatient cases in the Growth and Development clinic of Sanglah Hospital are global development delays (37.5\%), speech delays (22.6\%), ADHD (9.4\%), cerebral palsy $(7.4 \%)$, intellectual disability $(6.6 \%)$, clinically Down syndrome $(6.1 \%)$, gross motor delay $(5.2 \%)$, autism spectrum disorders (3.6\%), hearing loss $(1.3 \%)$, oppositional defiant disorder $(0.3 \%)$. These results are similar to the case of developmental disorders in the outpatient unit of RSU Dr. Soetomo Surabaya. The majority of cases in RSU Dr. Soetomo Surabaya is a delay in global development [3]. Research conducted by Ogundele in a Growth and Development clinic in the UK has different results, in which the study found that the most developmental disruption cases were speech delays (56\%), global development delays (33\%), behavioral disorders $(25 \%)$, social communication disorders (21\%), and autism spectrum disorders (19\%) [25].

The incidence of delayed global development is estimated to be $1-4 \%$ in children aged $<5$ years. The incidence of delayed speech is estimated to occur in $15 \%$ of children aged 24-29 months [14]. In this study, the majority of cases were delays in global development. This may be caused by the fact that the majority of patients seeking treatment at Sanglah Hospital have complex underlying illnesses. That is because Sanglah Hospital is the main referral center for the regions of Bali, NTB, NTT, East Timor where the diseases treated are complex diseases involving teams with multidisciplinary sciences.

\section{Conclusions}

Most cases of developmental disorders in the Growth and developmental clinic, Sanglah General Hospital are a global development delay. Child's gender, parents level of education, birth weight, and nutritional status has a significant role in children's development disorders. The majority of patients have the most common underlying disease, epilepsy.

This research is a retrospective study based on medical record data so that there can be much missed in the data collection process. This research was carried out in a growth and development clinic at a type A hospital in Indonesia. The results of this study may be similar to type A health services elsewhere but may differ in health services in different types. Prospective research is recommended to obtain better data.

\section{Disclosure}

The authors hereby declare no personal or professional conflicts of interest regarding any aspect of this study.

\section{Acknowledgements}

None declared.

\section{References}

[1] S. A. Rosenberg, Z. Duan, and C. C. Robinson. Prevalence of WHO, UNICEF. Early childhood development and disability: a discussion paper. 2012 [Accessed: 20 October 2018]. Available at:

http://apps.who.int/iris/bitstream/handle/10665/75355/978924 1504065_eng.pdf;jsessionid=72E3404F668875C0E449B0AE 236986DD? sequence $=1$.

[2] Cusick S, Georgieff M. The role of nutrition in brain development: the folden opportunity of the "First 10000 Days". J Pediatr. 2016; 175: pp. 16-21.

[3] Irwanto, Suryawan A, Narendra M. Penyimpangan tumbuh kembang anak. 2006 [Accessed: 20 October 2018]. Available at: https://www.researchgate.net/publication/305135658_PENYI MPANGAN_TUMBUH_KEMBANG_ANAK.

[4] Poon J, LaRosa A, Pai G. Developmental delay: timely identification and assessment. Indian Pediatrics. 2010; 47: pp. 415-22.

[5] Scharf R, Scharf G, Stroustrup A. Developmental milestone. Peds in Review. 2016; 37 (1): pp. 25-38.

[6] Council on Children With Disabilities, Section on Developmental Behavioral Pediatrics, Bright Futures Steering Committee, Medical Home Initiatives for Children With Special Needs Project Advisory Committee. Identifying infants and young children with developmental disorders in the medical home: an algorithm for developmental surveillance and screening. Pediatrics. 2006; 118: pp. 405-420.

[7] WHO. Nurturing Care for Early Childhood Development. 2018 [Accessed: 20 October 2018]. Available at: https://www.who.int/maternal_child_adolescent/child/nurturin g-care-framework/en/.

[8] Litbangkes B. Riset kesehatan dasar. Jakarta: Kementerian Kesehatan Republik Indonesia. 2010 [Accessed: 20 October 2018]. Available at: http://www.depkes.go.id/resources/download/pusdatin/profil-k esehatan-indonesia/profil-kesehatan-indonesia-2013.pdf.

[9] Ikatan Dokter Anak Indonesia. Mengenal keterlambatan perkembangan umum pada anak. 2013 [Accessed: 2 August 2019]. Available at: http://www.idai.or.id/artikel/seputar-kesehatan-anak/mengenal -keterlambatan-perkembangan-umum-pada-anak.

[10] Kementrian Kesehatan RI. Pedoman pelaksanaan stimulasi, deteksi dan intervensi dini tumbuh kembang anak. Jakarta: Bakti husada; 2016.

[11] Kementrian Kesehatan RI. Pedoman Penanganan Kasus Rujukan Kelainan Tumbuh Kembang Balita. Jakarta: Kementrian Kesehatan RI; 2010.

[12] Shevell, M. I., Majnemer, A., Rosenbaum, P., Abrahamowicz, M. Profile of referrals for early childhood developmental delay to ambulatory subspeciality clinics. J Child Neurol. 2001; 16: pp. 645-50.

[13] Akbari S, Montazeri S, Torabi F, Amiri S, Soleimani F, Majd H. Correlation between anthoropometric indices at birth and developmental delay in children aged 4-60 months in Isfahan, Iran. Int J Gen Med. 2012; 5: pp. 683-7. 
[14] Suwarba IGN, Widodo D, Handryastuti R. Profil klinis dan Etiologi Pasien Keterlambatan Perkembangan Global di Rumah Sakit Cipto Mangunkusumo Jakarta. Sari Pediatri. 2008; 10 (4): pp. 255-61.

[15] Goldman. Opinion: sex, gender and the diagnosis of autism- a biosocialview of the male preponderance. Res Autism Spectr Disord. 2013; 7: pp. 1-8.

[16] Charan GS, Vagha J. Study of perinatal factors in children with developmental delay. Int J Contemp pediatr. 2017; 4 (1): pp. 182-90.

[17] Badan Penelitian dan Pengembangan Kesehatan Kementerian Kesehatan RI. Riset Kesehatan Dasar. 2018 [Accessed: 1 June 2019]. Available

at: http://www.kesmas.kemkes.go.id/assets/upload/dir_519d41d8 cd98f00/files/Hasil-riskesdas-2018_1274.pdf.

[18] Schieve LA, Tian LH, Rankin K, Kogan MD, Yeargin-Allsopp M, Visser S, Rosenberg D. Population impact of pretrem birth and low birth weight on developmental disabilities in US Children. Ann Epidemiol. 2016; 26: pp. 267-74.

[19] Vameghi R, Akbari S, Sajjadi H, Sajedi F, Alavimajd H. Corelation between mothers' depression and developmental delay in infants aged 6-18 months. Global Jurnal of Health Science. 2015; 8: pp. 11-8.
[20] Halpern, R., Giugliani, R., Victora, C., Barros, F., Horta, B. Risk factors for suspicion of developmental delay at 12 Month of age. J Pediatr. 2000; 76: pp. 421-8.

[21] Chittleborough C, Lawlor D, Lynch J. Young maternal age and poor child development: predictive validity from a bith cohort. Pediatrics 2011; 127: pp. 1-9.

[22] Marshall J. Parent pathways: recognition and responses to developmental delays in young children. Graduate Theses and Dissertations; 2013.

[23] Chen CI, Chen CL, Wong MK, Chung CY, Chen CH, Sun CH. Clinical analysis of 1048 children with developmental delay. Chang Gung Med J. 2002; 25: pp. 743-9.

[24] Oeseburg B, Dijkstra GJ, Groothoff JW, Reijneveld SA, Jansen DEMC. Prevalence of chronic health conditions in children with intellectual disability: a systematic literature review. Intellect Dev Disabil. 2011; 49: pp. 59-85.

[25] Ogundele M. A Multidisciplinary approach to the assessment and management of pre-school age neuro-developmental disorders: a local Experience. J Nursing Care Pract. 2017; 1: pp. $1-12$. 